\title{
Language politeness performed by politicians in the discourse of jakarta election 2017 at online portal news
}

\author{
Widya Pangestika ${ }^{1}$, Agustina ${ }^{2}$, Ngusman Abdul Manaf ${ }^{3}$ \\ ${ }^{123}$ Univeritas Negeri Padang, Padang - Indonesia,(widyapangestika289@gmail.com)
}

\begin{abstract}
Jakarta Election 2017 was a phenomenal one from many points of views including aspect of language use as political tool. Therefore, this study aims to describe the politeness level of politicians in the discourse of Jakarta election 2017 at online portal news. This research used a qualitative approach with descriptive method. Analyzing the data was exercised by content analysis method with the application of language politeness theory from Brown-Levinson and Leech. Based on data analysis, politicians are more dominant to convey their ideas through a rhetorical style of irony, expressive speech acts, and vague strategies; they also tend to violate rather than adhere to the politeness principle so, it was 'high potential' to threaten the face of the intended person or party. Based on the findings of this research, the level of language politeness performed by politicians in Jakarta Election is represented in three divisions; about $48 \%$ of comments of the politicians are at an 'impolite', $15 \%$ are at 'less polite' level, and only $36 \%$ are in the 'polite' category.
\end{abstract}

Keywords: language politeness, speech acts, political discourse

This is an open access article distributed under the Creative Commons 4.0 Attribution License, which permits unrestricted use, distribution, and reproduction in any medium, provided the original work is properly cited. $\odot 2018$ by author and Faculty of education, Universitas Negeri Padang.

\section{Introduction}

Jakarta 2017 Elections in became the most controversial regional elections as Agustina (2017, p. 130) where there are four things underlying the problems are as follows. Firstly, although DKI Jakarta is just one of the provinces in Indonesia, but DKI Jakarta is also the capital city of Indonesia and the gateway of Indonesia. Secondly, the Jakarta Election is allegedly loaded with the political interests of two major groups, which are the supporter of the government and the opposite side or contrary to the government, each with its supporting parties. Third, one of the candidates of governor and also the person who governed at that time, was involved in a SARA case that sparked a prolonged polemic, not only in Jakarta but also in other parts of Indonesia region. Fourth, based on some experts' estimation, Jakarta Election is a determinant barometer of political temperature of Indonesia. One of the causes of such problems occurs because the uses of language are widely misused by the parties involved in Jakarta Election; one of them is the politician.

Politicians are one group of people who are expected to communicate with polite because basically human life is never separated from politics.Thus, it can be said that politicians are role models for 
society.Furthermore, politicians are identical with someone who is capable of using words in public with the aim of criticizing, advising, suggesting, refuting, blaming, justifying, attacking, persuading, and seducing. The language used by politicians to achieve their goals varies widely. However, politicians are frequently also to speak impolitely, lead to rude, and tend to twist the facts.This is evidenced also from some of the results of research, such as in Pakistan (Yasmeen, Jabeen, \&Akram, 2014);in Indonesia (Mujianto, 2013; Setyawan, 2015; Luthfiyanti, 2017; Wulandari, 2017).

From the results of these studies, it appears that politicians still often speak in polite not to express opinions. It is proven by the politician's neglect of the elements of politeness as well as violations of the politeness principle resulting in a bad impact for speakers and the receivers. This is also triggered by the freedom of the press in Indonesia which has been increasingly liberal since the reform era (Ardianto\&Erdinaya, 2004: 155). This condition is in harmony with research conducted by Peterson (2015) in India on the connection between the press and democracy. Such facts is also occurred in Jakarta 2017 Election, which according to Agustina (2017 p. 130) is the most phenomenal and controversial elections because it is not only brimming with political content, but also has implications for the use of language as its political means.

Based on above phenomenon, the problem of this research is "How is the form of language politeness performed by politicians in political discourse of Jakarta 2017 Election at the online news portal?" with four focuses of discussion. The focuses are (1) (1) what kinds of speech acts are used as the manifestation of politeness, (2) what figures of speech are used as expression of politeness, (3) what speech strategies are used, and (4) how does the application of politeness principles perfomed by politicians in political discourse of Jakarta 2017 Election.

\section{Method}

The type of this research was qualitative-descriptive research where to describe the object as clear as possible and to explain the data accurately, systematically, and comprehensively. In this case, the role of the researcher was as a key instrument.Technique of collecting data was done in combination;analysis techniques were inductive; the results of research emphasized mainly in the meaning than generalization of the data (Sugiyono, 2009, p. 285);Sudaryanto, 1992, p. 62). The data of this research were the speeches of politicians in political discourse of Jakarta 2017 Election at online news portal specifically in detik.com, kompas.com, vivanews.com, merdekaand liputan6.com. The data were taken randomly from January to April 2017 and were collected with the techniques of note-taking and documentation,while analyzing data by using Miles and Huberman's theory with three stages:reducing data, presenting data, and drawing conclusions.

\section{Results and Discussion}

Based on the identification of data in accordance with the proposed problem, it is obtained a classification of the data of verbal violence by politicians in the discourse of the Jakarta Election and its implications for language politeness as shown in the following table. 
Table 1. Representation of Language Politeness of Politicians in the the discourse of Jakarta Election in Mass Media

\begin{tabular}{|c|c|c|c|c|c|c|c|c|c|c|c|}
\hline \multicolumn{7}{|c|}{ Element of Politeness } & \multicolumn{5}{|c|}{ Level of politeness } \\
\hline $\begin{array}{l}\text { Speech } \\
\text { type }\end{array}$ & Total & $\begin{array}{l}\text { Language } \\
\text { style and } \\
\text { figure of } \\
\text { speech }\end{array}$ & Total & $\begin{array}{l}\text { Speech } \\
\text { strategy }\end{array}$ & $\begin{array}{l}\text { Tota } \\
1\end{array}$ & $\begin{array}{l}\text { Politeness } \\
\text { principles }\end{array}$ & $\begin{array}{l}\text { Adh } \\
\text { ere }\end{array}$ & $\begin{array}{l}\text { Viola } \\
\text { te }\end{array}$ & $\begin{array}{l}\text { Percen } \\
\text { tages }\end{array}$ & FTA & Category \\
\hline $\begin{array}{l}\text { Ekspres } \\
\text { if }\end{array}$ & 49 & Sarkasme & 26 & $\begin{array}{l}\text { Terus } \\
\text { Terang }\end{array}$ & 31 & $\begin{array}{l}\text { Kebijaksana } \\
\text { an }\end{array}$ & 1 & 10 & 48 & $\begin{array}{l}\text { Ting } \\
\text { gi }\end{array}$ & $\begin{array}{l}\text { Tdk } \\
\text { santun }\end{array}$ \\
\hline Direktif & 12 & Sinisme & 31 & $\begin{array}{l}\text { KstnNega } \\
\text { tif }\end{array}$ & 22 & $\begin{array}{l}\text { Kedrmwana } \\
\mathrm{n}\end{array}$ & 1 & 3 & 15 & Agak & Kurangsa \\
\hline Asertif & 35 & Ironi & 40 & $\begin{array}{l}\text { KsntnPosi } \\
\text { tif }\end{array}$ & 11 & Pujian & 3 & 53 & & $\begin{array}{l}\text { tingg } \\
\text { i }\end{array}$ & ntun \\
\hline $\begin{array}{l}\text { Deklara } \\
\text { si }\end{array}$ & 7 & $\begin{array}{l}\text { Antifrasi } \\
\mathrm{s}\end{array}$ & 5 & $\begin{array}{l}\text { Samar- } \\
\text { samar }\end{array}$ & 40 & $\begin{array}{l}\text { KrendhanH } \\
\text { ati }\end{array}$ & - & 7 & & & \\
\hline Komisif & 1 & Alusio & 2 & & & $\begin{array}{l}\text { Kesepakatan } \\
\text { Kesimpatian }\end{array}$ & - & $\begin{array}{r}21 \\
3\end{array}$ & 36 & $\begin{array}{l}\text { Rend } \\
\text { ah\& }\end{array}$ & Santun \\
\hline & 104 & & 104 & & 104 & & 7 & 97 & 100 & $\begin{array}{l}\text { netra } \\
1\end{array}$ & \\
\hline
\end{tabular}

\section{The Use of Speech Acts}

In conveying their opinions, the most dominant speech acts used by politicians is expressive (49 data) in the form of praising, criticizing, scolding, insinuating, condemning, and accusing.Furthermore, politicians also frequently used speech acts of representative (35 data) in the form of stating, showing, complaining, boasting, expressing opinions, and reporting; the third one is directive speech acts (12 data) in the form of warning, suggesting, demanding, ordering, inviting, and pleading. The least-used speech act is declarative (7 data) in the form of prohibiting: and and commissive type $(1$ data) in the form of threatening. The types of speech acts are shown in the following examples: representative (1), directive (2), expressive (3), commissive (4), and declarative (5).

1. There is no need for court to follow FadliZon's inconsequent interpretation where there is on the behalf of the community?" said by former supporter group member (DT24, C / 28/04/2017).

"Masak putusan pengadilan harus mengikuti tafsir semau-maunya Fadli Zon yang mengatasnamakan masyarakat?"sambung mantan anggota timses (DT24,C/28/04/2017).

2. I guess if he want to be dragged into coalition issues on Jakarta election, Mr Jokowi will suffer a big-loss," said Yandri (KP3, Y: 19/02/2017)

"Saya kira kalau berpikir demikian Pak Jokowi yang rugi untuk mau diseret-seret kemasalah koalisi pilkada di DKI," kata Yandri(KP3,Y:19/02/2017)

3. Islam is not as frightening as it is. Islam is embracing people, not hitting people," closed by Djarot (DT3, D: 20/03/2017).

"Islam nggak sangar kayak begitu. Islam itu sejuk, damai.Islam itu merangkul, bukan mukul,"tutup Djarot (DT3,D:20/03/2017).

4. Yes, from the beginning of the process of Jakarta Election PAN wants to find an alternative choice to the people of Jakarta. From the beginning, PAN was not going to support Ahok because of the 
character and ethics do not match to the party" said Yandri on the same occasion (LP3, YS: 18/02/2017).

“Ya, dari awal proses pilkada DKI PAN ingin mencari alternatif pilihan kepada rakyat DKI. Sejak awal PAN sudah bersikap tidak akan mendukung Ahok karena dari karakter dan etika tidak cocok sama PAN,"ucapYandri dalam kesempatan yang sama (LP3,YS:18/02/2017).

5. "Maybe the government should not intervene and better take care of bigger business, let politics run in accordance with existing rules" he concluded (RM10,E:30/03/2017).

"Dan pemerintah tidak usah ikut mengintervensi lebih baik mengurusi urusan yang lebihbesar, biarkan politik berjalan sesuai dengan aturan yang sudah ada," pungkasnya (RM10:30/03/2017).

In speech (1), politician uses the speech act of representative in the form of complaining on the sentence "there is no need for court to follow FadliZon's inconsequent interpretation" toward an unfair decision by the court because of following FadliZon's opinions.In the statement (2) the politician performs a directive speech act in the form of warning on the sentence "Mr Jokowi will suffer a big-loss" with the aim of providing a warning to Mr. Jokowi to not interfere or involve in Jakarta 2017 Electionbecause it will just drag Jokowi into a trouble. Utterance (3) is a type of expressive speech acts by way of criticism; it is aimed at those who use the issue of SARA in Jakarta 2017 Election. Further, speeches no. (4) and (5) are conveyed with commissive speech acts in the form of threatening.

The Use of Language Style and Figure of Speech

The politicians while expressing their opinions recurrently applyfigurative speech of sarcasm. It is evident that from a total of 104 data, the most dominant occurence is figurative speech of irony (40 data), cynicism (31 data), sarcasm (26 data), antifrasis(5 data), and pun (2 data). Some of these are seen in the following samples: irony (6), cynicism (7), sarcasm, (8), antiphrasis (9), and pun(10).

6. Me myself as KetumFuhab, according to Islamic teachings, it is a must to choose a leader who loves and is being loved by Allah. We are to choose leaders who believe in Allah, said Chairman of the Fuhab, KH SyukronMakmun (LP9, F: 23/02/2017).

"Kami selaku Ketum Fuhab sesuai ajaran Islam wajib memilih pemimpin yang mencintai dan dicintai Allah. Kami wajib memilih pemimpin yang beriman kepada Allah," kata Ketua Umum Fuhab KH Syukron Makmun (LP9,F:23/02/2017).

7. I think only the defendant (Ahok) alone talks about this (Al-Maidah verse 51 in political affairs), so it becomes a polemic that should not have happened," he said in a hearing at the Auditorium of the Ministry of Agriculture (LP5, MA: 21/02/2017).

"Saya rasa hanyaterdakwa (Ahok) saja yang berbicarasoalini (Al-Maidah Ayat 51) sehingga menjadi polemik yang seharusnya tak perlu terjadi," ucap dia dalam persidangan di Auditorium KementerianPertanian (LP5,MA:21/02/2017).

8. Jakarta Election is over, but FadliZon still shows a childish attitude. Or maybe FadliZon has another agenda by continuing to corner Ahok and glorifying SARA sentiments?" (DT26, C: 28/04/2017).

"Pilkada DKI sudah selesai, tetapi Fadli Zon masih menunjukkan sikap kekanak-kanakan. Atau jangan-jangan Fadli Zon punya agenda lain dengan terus memojokkan Ahok dan menggoreng sentimen SARA?"(DT26,C:28/04/2017).

9. There is no original program from Ahok-Djarot. The whole programs are others, said the pair number 3," saidAhok (DT8, AH: 22/03/2017). 
"Mana adasih program asli Ahok-Djarot. Semuakan program orang, kata pasangan nomor 3," ujar Ahok sambil (DT8, AH: 22/03/2017).

10. The mosque is a place to proclaim all the good things. Place for embracingnotto hit, for inviting not to mock. No more mutually disbelieving and hypocritical" says Yenny (DT28, Y: 29/04/2017).

"Masjid menjadi tempat mengumandangkan semua hal yang baik. Merangkul bukan memukul, mengajak bukan mengejek. Tidak ada lagi saling mengkafirkan dan memunafikkan," tuturYenny (DT28,Y:29/04/2017).

The use of figurative speech of irony in data (6) is characterized by a sentence .. Islamic teachings must choose a leader who loves and is being loved by Allah because the paragon already existswhich is delivered in an indirect way, but the speech is clearlythreatening the face of the receiver. Furthermore, the use of figurative speech of cynicismin data (7) is indicated by a statementonly him (Ahok) which complain about this (Al-Maidah Verse 51),so it becomes a polemic that should not have happened. Moreover, the use of figurative speech of sacrcasm in data (8) is marked by a statementchildish attitude and by continuing to corner Ahok and glorifying SARA sentimentswhich is delivered directly so as to cause pain to the party in question.As well in utterance (9) it is conveyed with an figurative speech of antiphrasis that mocks the receiverby using statements that are meaningfully reversed from the words used.In contrast, data (10) is conveyed with a figurative speech of Pun where the speaker uses an allusion with similar sound to tease the hearer in the worda:to embracenotto hit, to invite not to mock. The similarity of sounds spoken by speakers (Yenny) intends toto insinuate the parties who use the mosque for a place to spread SARA issues than to spread goodness.

\section{The Use of Speech Strategy}

The politicians in delivering their comments related to Jakarta 2017 Election at the online news portaluse four politeness strategies such as bald on record (31 data), negative politeness (22 data) positive politeness ( 12 data) and vague politeness (40 data). Among its uses, it can be seen in the following example, bald on record (11), negative politeness (12), positive politeness (13), and vague politeness (14-15)

11. The thing is, they are just brazen-face. Thug, he thinks I can not stop him. Hence, I want to ask the Police to act. He thinks we are not governors anymore, "he said (VN17, AA: 25/04/2017).

"Masalahnya, mereka kurang ajar saja. Preman, dia pikir saya sudah enggak bisa tindak dia. Makanya, saya mau minta Kepolisian tindak. Dia merasa kita sudah bukan gubernur lagikan," ujarnya (VN17,AA: 25/04/2017).

12. The debate is good. I am present to watch the debate and also as an observer. I am a former resident of Jakarta.I almost ten years in Jakarta. Jakarta needs smart and nimble hands.It only exists in number two" said Antasari (KP1, AS: 27/03/2017).

"Debatnya bagus. Saya hadi rmenonton debat, saya kebetulan di sini pengamat. Saya mantan penduduk Jakarta. Hampir sepuluh tahun di Jakarta. Jakarta perlu tangan cerdas dan gesit. Itua da di nomor dua," kata Antasari (KP1,AS:27/03/2017).

13. Honorable politicians, whom I respect, please behave as statesmen. Jakarta election is officially over. Now is the time to focus on building a better Jakarta," says Charles (DT271, CH: 28/04/2017).

"Bapak-bapak politikus santun yang saya hormati, tolonglah berperilaku sebagai negarawan. Pilkada DKI sudah selesai. Sekarang waktunya fokus membangun Jakarta yang lebih baik," ujar Charles (DT271,CH:28/04/2017). 
14. "Why did I convey this? There are 480 more polling stations that we won in the numbers are above 90 percent. Is it possible (if) in that place, we wonabou 90 percent?It is a joke. But I also do not know what happened. So I say funny, "said Anies (DT2, AN: 19/03/2017).

"Kenapa saya sampaikan ini? Ada 480 lebih TPS yang angka kemenangannya di atas 90 persen.Mungkin nggak (bila) di tempat itu 90 persen menang? Bapak-ibu, ini lucu. Tapi saya juga tidak tahua pa yang terjadi. Makanya saya bilang lucu," ujar Anies (DT2,AN:19/03/2017).

The use of bald on record strategy in data (11) is conveyed directly to denounce the attitude of the intended party by using wordjust a brazen-facewhich can threaten and lose the face of the partyreferred in the speech. In the data (12), the speaker uses a positive politeness strategy through the sentenceJakarta needs smart and nimble hands. It only exists in number twowhich aims to give spirit to the intended party. Furthermore, in the data (13) politicians' comments were delivered using a negative politeness strategy with phrases Honorable politicians whom I respectwith a view to respect the receiver despite the softening of the power of the illucution, so the speech was perceived much more polite. Another case with speech (14), comments are delivered with a vague strategy. That is, speaker ridicules the receiver in an indirect way or impliedly.

\section{The Use of Politeness Principle}

Of a total of 104 data, only 7 utterances comply with the politeness principle. Meanwhile,there are 98 comments clearly violate the politeness principle which includes tact (10 data), generosity (3 data), approbation (53 data), modesty (7 data), agreement (21 data) and sympathy (3 data). The violations isshown in the following sample data such as tact (15), generosity (16), approbation (17), modesty (18), agreement (19) and sympathy (20).

15. "Maybe the government should not intervene and better take care of bigger business, let politics run in accordance with existing rules" he concluded (RM10,E:30/03/2017).

"Dan pemerintah tidak usah ikut mengintervensi lebih baik mengurusi urusan yang lebih besar, biarkan politik berjalan sesuai dengan aturan yang sudah ada," pungkasnya (RM10,E:30/03/2017).

16. "I'm sure this sort of thing exists in every region. Therefore I ask the authorities to reveal everything, who printed it, who ordered it, and who financed it. Because this is clearly detrimental to us, "said Taufik (VN4, T: 14/02/2017).

"Saya yakin yang seperti ini di setiap wilayah ada. Oleh karena itu saya minta aparat dapat mengungkap semuanya, siapa yang mencetak, siapa yang menyuruh, dan siapa yang membiayainya. Karena ini jelas merugikan kami," kata Taufik (VN4,T:14/02/2017).

17. "I do not (imitate). The kopiah (cap) have been used from a long time ago. They (other candidates) are just big-headedif Mr. Djarot imitates them. MrSukarno also wore the cap. Do not be over-confident, hehe ...," said Toni (LP10, T: 24/03/2017).

"Enggak (niru). Kopiahkan sudah dipakai dari sejak dulu. GR (gede rasa) saja calon lain itu kalau anggap Pak Djarot meniru mereka. Bung Karno dari dulu pakai peci. Jangan GR hehe...," ucap Toni (LP10,T:24/03/2017).

18. "If I wear the cap, it would be gorgeous, said Ahok jokingly (LP11, AH / 24/03/2017).

"Kalau pakai peci terlalu ganteng, "selorohAhok (LP11,AH/24/03/2017).

19. "If the defendant (Ahok) does not talk about Al Maidah, it would be easy. However, it is a political competition. There is no problem if the defendant did not discuss (Al Maidah 51) in PulauSeribu," he said (LP4, MA: 21/02/2017). 
"Kalau terdakwa (Ahok) tidak sampaikan surat Al Maidah, tidak masalah. Pilgub DKI ini.Tak ada masalah kalau terdakwa tak sebut ucapan (Al Maidah 51) di PulauSeribu," ucap dia (LP4,MA:21/02/2017).

20. "Yes, from the beginning of the process of Jakarta Election PAN wants to find an alternative choice to the people of Jakarta. From the beginning, PAN was not going to support Ahok because of the character and ethics do not match to the party" said Yandri on the same occasion (LP3, YS: 18/02/2017).

"Ya, dari awal proses pilkada DKI PAN ingin mencari alternative pilihan kepada rakyat DKI. Sejaka wal PAN sudah bersikap tidak akan mendukung Ahok karena dari karakter dan etika tidak cocok sama PAN," ucap Yandri dalam kesempatan yang sama (LP3,YS:18/02/2017).

Violation of the tact principle is seen in the data (15) because the speech gives harm to the intended party. It is seen in the use of a statement in bold with the intention of forbidding the government not to interfere with the speaker's affairs. In the data (16), it also seen that the speaker violates the politeness principle of generosity with the use of utterance ...I ask the apparatus to reveal everythingwith the intention of asking officials to immediately reveal the mastermind behind the black campaign. That statement of request mainly benefited the speaker, but indirectly could harm the interested party. Furthermore, in the data (17), the speech violates the approbation maxim, by way of criticizing the opponent's face by using the expressionthey (other candidates) are just big-headedwhich intends to criticize other candidates who are considered too confident. Then, the utterance (18) violates the principle of modesty through the use of a sentenceIf I wear a peci(cap), (it would be) too gorgeous. In this case, the politician praises himself by declaring proudness about his appearance. Violations of the politeness principle also occur in speech (19) namely agreement principle; while the utterance (20) violates the sympathy principle.

Based on data analysis toward the four elements of politeness as the purpose of this study, it can be represented into the four points. First, based on the dominance of politicians' choice on expressive speech acts (49 data), the use sarcasmic language style (26 data), the use bald on record strategy(31 data) as well as a total violation of the politeness principle ( 97 data) it shows that $48 \%$ of the total speech of the politicians is on a high level of FTA. This is seen in the speeches of the politicians which dominantly use the expressive speech acts in the form of praising, criticizing, insinuating, disgracing, and evenblasting.

Based on these explanations, these politicians' comments potentially threaten a positive face of the interlocutors, as described by Brown and Levinson (1987, p.62); the actions that threaten the positive face are expression of criticism, degrading or humiliating acts, complaining, and disturbing, blaming, insulting, and the like. In addition, the expression of comments is conveyed in a rough and direct way, so that speaker commonly violates the politeness principle. Thus, based on that explanation, speakers are in the classification of 'impolite'.In line with 'scale of indirectness' parameter from BulmKulka (in Amir, et al., 2006: 14) where "the more direct an utterance, the more impolite it is and vice versa."This classification is indicated by red color in the table which indicates that the utterances belong to a 'dangerous' category.

Second, the less dominant choice is in the types of directive and commissive speech acts (13 data), the use of cynical language style (31 data), the use negative politeness strategy (22 data). It represent that $15 \%$ of the total speechsand statements of the politicians is on a quite-high level of FTA. It can be 
seen that the politicians frequently use the type of directive speech, in the form of warning, demanding, inviting, and ordering where it has the potential to threaten the opponent's face, especially the negative face. In accordance with that opinion, Brown and Levinson (1987: 62) state that speech acts that threaten the negative face, among them are the expression of hatred, anger, order, warning, threat, and so forth. Thus, the speakers in this case are in the 'less polite' classification. This classification is indicated by yellow color in the table which indicates that the utterances belong to a 'dangerous' category.

Thirdly, although this choice is fairly dominant in the types of representative and declarative (42 data), the choice of figurative speech of irony, antifrasis, and pun (47 data), and the use of positive and vague politeness strategies (51 data), but $36 \%$ of politicians's comments are on low level of FTA. This is due to the use of representative and declarative speech acts with forms stating, reporting, mentioning, showing and so forth which is expressed indirectly and properly. This is in agreement with Grice's theory (in Pranowo, 2008: 362) "Choose a statement that does not underestimate the status of the hearer." Although the comment is aimed at insinuating or criticizing the receiver, the indirect way of delivery makes this politican's speeches include into the category of "polite." This fact is in line with 'scale of indirectness' parameter from Bulm-Kulka (1985:14) where "the more indirect an utterance, the more polite it is." This classification is indicated by green color in the table which indicates that the utterances belong to a 'less dangerous' category.

\section{Conclusion}

Based on the data analysis and discussion, it can be concluded as follows. First, the most used of speech act by politicians in the political discourse of Jakarta 2017 Election at online news portal is expressive and representative type.Second, politicians tend to choose ironical and cynical language style in the political discourse of Jakarta 2017 Election at the online news portal. Third, the speech strategy frequently used by these politicians in the political discourse of Jakarta 2017 Election is a vague and bald on record strategy. Fourth, politicians primarily violate the principles of politeness rather than obey the principles. Fifth, the level of politeness shown by politicians in the political discourse of the elections of DKI Jakarta 2017 can be classified into three categories, (1) impolite $(48 \%)$, (2) less polite (15\%), (3) quite polite (36\%). Based on the percentage used, although there are still politicians who speak impolite and quite-polite, but in general, the level of language politeness of politicians in the political discourse of Jakarta 2017 Election is in a 'less-polite' position.

\section{Acknowledgments}

Author would like to thank Prof. Dr. Agustina, M.Hum as advisor I and Dr. Ngusman, M.Hum as a advisor II patiently and willingly have given their time, input and guidance to the author in completing this research. Thank you author say to the parents who always pray author in completing this research. Furthermore, author say thank you to friends also gave inputs to the completion of this research. 


\section{Reference}

Agustina. (2017). Kekerasan verbal dalam pilkada DKI: mengungkap tingkat kesantunan masyarakat berwacana politik. Prosiding Bahasa dan Sastra Indonesia dalam Gamitan Masyarakat Multikultural. Padang: Jurusan Bahasa dan Sastra Indonesia FBS Universitas Padang.

Brown, P \&Levinson, S. (1987). Politenes, Some Universal in Language Usage. Cambridge: Cambridge University Press.

Luthfiyanti, L. (2017). Kesantunandalam acaratvindonesia lawyers club (ilc) di tvone.Stilistika: Jurnal Bahasa, Sastra, danPengajarannya, 2(1).

Mujianto, G. (2013). Tutura pejabat negara dalam berita "Korupsi" pada media massa cetak. Jurnal Humanity, 8(2).

Nisa, F. (2016). Pelanggaran prinsip kesantunan dalam wacana tutur basuki tjahaja purnama (ahok). STILISTIKA: Jurnal Bahasa, Sastra, dan Pengajaran, 1(1), 19-30.

Nuolijarvi, P., Tittula, L. (2010). Irony in political television debates. ELSAVIER: Journal of Pragmatics. 2(43), 572-587.

Paterson, M.A. (2015). Speaking ofnews: Press, democracy, and metapragmatics in a changing India.American Ethnologis: Jounal of Amerivan Ethnological and Society. 4(42), 673-678.

Setyawan,A. H. (2015). Prinsip-prinsip Kesopanan pada Rapat Politik Margaret Thatcher dalam Film The Iron Lady. Jurnal Sosio-Humaniora, 6(1).

Syahrul, R. (2008). Pragmatik Kesantunan Berbahasa Menyibak Fenomena Bahasa Indonesia Guru dan Siswa. Padang: UNP Press.

Sugiyono.(2009). Metode Penelitian Pendidikan. Bandung: Alfabeta.

Sugiyono. (2012). Metode Penelitian Kuantitatif, Kualitatif, dan R\&D. Bandung: AnggotalkatanPenerbit Indonesia (IKAPI).

Tarigan, H. G. (2013). Pengajaran Gaya Bahasa. 2013. Bandung: Angkasa.

Wijana, I. D. P. (2009). AnalisisWacanaPragmatik: KajianTeoridanAnalisis. Surakarta. Surakarta: Yuma Pustaka.

Wulandari, B. (2017). Kesantunan berbahasa dalam wacana humor politik pada pilpres 2014 di akun twitter@ CapresJokes. Jurnal Ilmiah Edukasi ESosial, 6(1), 12-22.

Yasmeen, R., Jabeen, M., Akram, A. (2014). Politeness an the language of pakistani politicians. SAVAP Internasional. 5(3), 245-253.

Yule, G. (2006). Pragmatik,(Terjemahan Indah FajarWahyuni). Yogyakarta: PustakaPelajar.

Yusri.(2015).Pelanggaran kesopanan berbahasa dalam komunikasi politik pada pemilihan komunikasi politik pada pemilihan Gubernur Sulawesi Selatan 2013. PAROLE: Journal of Linguistics and Education, 5(1), 26-39. 